\title{
articles JOURNALISM AS JUSTIfIED articulos TRUE BELIEF
}

Copyright (c) 2015 SBPjor / Associação Brasileira de Pesquisadores em Jornalismo
SÍLVIA LISBOA

Universidade Federal do Rio Grande do Sul, Brazil

MARCIA BENETTI

Universidade Federal do Rio Grande do Sul, Brazil

\begin{abstract}
If it is important to think of journalism as a form of knowledge, then how does it become knowledge? How does this process work? In order to answer this question, this article proposes a new understanding of journalism as a subject; presenting it as a justified true belief. We think of journalism being based on pillars of truth and justification, conditions necessary in order for Epistemology to grant it the status of knowledge. We address the concept of truth and show how journalistic reports are justified to the public as well as consider the central role of credibility in this process. We add to the epistemic conception by using concepts of discourse that help to understand how journalism provides evidence through its intentions, its authority and its ability. This evidence acts like a guide for the reader towards forming opinions on journalistic reports and recognizing journalism as a form of knowledge.
\end{abstract}

Keywords: Journalism. Philosophy. Knowledge. Truth.Credibility.

\section{O JORNALISMO COMO CRENÇA VERDADEIRA JUSTIFICADA}

RESUMO - Se é pertinente considerar o jornalismo como uma forma de conhecimento, então como ele se torna um conhecimento? Como funciona este processo? Para responder a essa questão, este artigo propõe uma nova compreensão sobre o estatuto do jornalismo como disciplina, afirmando-o como uma crença verdadeira justificada. Pensamos o jornalismo a partir dos pilares da verdade e da justificação, condições necessárias para que a Epistemologia Ihe conceda o estatuto de conhecimento. Abordamos o conceito de verdade, mostramos como os relatos jornalísticos se justificam perante o público e tratamos do papel central da credibilidade neste processo. Para complementar a concepção epistêmica, recorremos a conceitos do discurso que ajudam a compreender como o jornalismo provém evidências acerca de suas intenções, de sua autoridade e de sua competência. Essas evidências servem de guia para o leitor formar juízos sobre os relatos jornalísticos e reconhecer o jornalismo como um modo de conhecimento.

Palavras-chave: Jornalismo. Filosofia. Conhecimento. Verdade. Credibilidade.

\section{PERIODISMO COMO CREENCIA VERDADERA JUSTIFICADA}

RESUMEN - Si es pertinente considerar el periodismo como una forma de conocimiento, de que manera él se convierte en un conocimiento? ¿Cómo ocurre este proceso? Para responder a esta cuestión, este artículo propone una nueva comprensión del periodismo como una disciplina, considerándolo como una creencia verdadera justificada. Pensamos el periodismo desde de los pilares de la verdad y de la justificación, condiciones necesarias 
para la Epistemología tratarle como un conocimiento. Empezamos por el concepto de verdad, presentamos como los relatos periodísticos se justifican al público y el rol central de la credibilidad en este proceso. Para complementar la concepción epistémica, utilizamos conceptos de discurso que ayudan a entender cómo el periodismo presenta evidencias acerca de sus intenciones, su autoridad y cualificación. Estas evidencias sirven como un guía al lector en la formación de sus juicios sobre los relatos periodísticos y para el reconocimiento del periodismo como una forma de conocimiento.

Palabras-clave: Periodismo. Filosofía. Conocimiento. Verdad. Credibilidad.

\section{INTRODUCTION}

This article is based on a complex theoretical issue. If it is important to take journalism as a form of knowledge - a concept defended by Park (2008), Genro Filho(1987) and Meditsch (1992, 1997) and so many other researchers - thenhowisthis knowledge established? Howdoes journalism become knowledge? How does this process work? What elements does the subject need and what needs to be done so that, in the end, it is representative of the cognitive and epistemic status of journalism?

In this article we maintain that journalism needs tomeet three conditions in order to become knowledge: conditions of belief, truth andjustification. Basically, the subject believes that journalism tells the truth, and that this truth is justified by its discourse. If it is not, the way we see it, there is no construction of journalistic knowledge. To deal with this issue we turned to authors of philosophy to help us think through the process of constructing knowledge. Looking at this from a philosophical point of view of epistemology - also called the Theory of Knowledge - we maintain that journalism becomes knowledge through justified true belief'.

One of the main concepts implemented over the course of this text and directly related to trust is credibility. Credibility is constantly referred to as the most important value in journalism (BERGER, 1996) and exactly because of its importance, requires theoretical refining. Aware of its complexity, Lisboa (2012) proposes two components to the concept of credibility: constituted credibility (the one who enunciates) and perceived credibility (effectively attributed by the interlocutor). This distinction is important because the values that 
sustain perceived credibility - attributed by the reader - do not always correspond to the "canonical" values that make upthe journalistic ethos, and are generally associated to the constituted credibility "in journalism" or "the vehicle".Credibility has an intersubjective nature: in order for it to be a predicate, it cannot be a self-attributed quality; it is formed in the context of a relation and is dependent on the other subject's perspective. "A speaker's constituted credibilityhas toprecede the interlocutor's perspective, but it only obtains meaninginside an intersubjective relationship" (LISBOA, 2012, p. 15).

The debate on journalistic credibility is a complex one. The subject requires answers to concrete questions like "Is contemporary journalism still credible?" or "Did vehicle $X$ gain or lose credibility after case Y?" There are those who say that since the credibilityof some vehicles or journalists is dubious, then journalism does not havea presumption of credibility just because it is built on the pillars of truth and justification. The credibility of vehicles and journalists has been looked upon skeptically since the seventeenth century, as Peucer (2004) shows so well in his text written in 1690. What we are stating here is the necessity of presuming credibility in order for journalism to be a specific knowledge and nothing else. Credibility is therefore fundamental to our argument andnot just an accessory concept; as belief, truth and justification are materialized through credibility which we will demonstrate in short order. How can a subject presume that journalism is credible? By trusting that the journalistic discourse tells the truth.

From an epistemological point of view, journalistic discourse provides proofthrough its authority and intentions which guide the reader to form an opinionabout the reports. Perceived credibility is the result of an intense and constant negotiation of meanings between journalism and its public. The question lies in how journalism demonstratesits credibility to the reader while maintainingthe pillars of truth and justification; the necessary conditions in which philosophy recognizes journalism as knowledge.

\section{TRUTH IN JOURNALISM}

In order to understand journalism as justified true belief you need to analyze how truth and justification are presented. First, we will look at the idea of truth as it pertains to journalism. There are at least 
five distinct conceptions of truth in philosophy: 1) correspondence, 2) revelation, 3) conformity to a rule or concept 4) coherence and 5) utility (ABBAGNANO, 2007)2. Each one is important to the field of philosophy, but the first two are the most universal. Truth as correspondence is particularly useful towards understanding what makes journalism knowledge. We hold the idea that truth in journalism is supported by the connection its discourses (and enunciations) have with reality regarding the ontological existence of facts (AUSTIN, 1961). This theory makes the assumption that there is an external reality that does not depend on the observer for its existence (LISBOA, 2012). The propositional truth implied in the belief in journalism is supported in its relation of correspondence to reality.

The question of truthfulness is crucial to believing in an information source like journalism, its purpose being to describe and interpret reality. A journalistic report is built on strategic discourses that help the reader certify its authenticity or reasonableness of the facts and the value of explanations ${ }^{3}$. Charaudeau (2010) points to four frequently-used elements in journalism that serve as trustworthy guides for the truth: authenticity (supported by the simple existence of human beings on the earth), designation (the main function of an image for showing the world as it is), reasonableness (reconstitution of existence made possible through surveys, third-party testimony and investigation) and explanation (the reasons why things are the way they are).

When applying the Bayesian ${ }^{4}$ inference to a testimony in order to discover what practice would be best to promote the truth in reports, Goldman (1999) adds aspects like logic and authority of the source, similar to elements described by Charaudeau. Logic plays the role of authenticity and reasonableness. A report of atraffic jam accident at 3amlacks logic. But, if a transit authority reports on the accident, then the testimony becomes more credible. In journalism, discursive choices like special sources, photographs, the details of an event etc., make up a set of techniques created in order to transform the text into a credible report based on real facts. The reader not only identifies a journalistic text this way but is also capable of identifying elements within the text which help to measure the degree of loyalty between a report and a reported fact.

However, the question of truthfulness in journalism is a complex one. An analysis on the level of accuracy of journalistic reports, carried out by Cox and Goldman (1994), revealed that the 
exactness of reports is not only a question ofthe statements and descriptions being true, but to what degree the facts might be distorted, or not. They give the example of a report from an official regardedas a highly reliable sourcecalled $p$. The issue is that $p$ is false, but the material does not reveal this, it just attributes the statement to the source. The incomplete or only point of view distorts the story and leads readers to conclusions that are not true ${ }^{5}$.

The problem of truthfulness is that it imposes certain conditions beyond simple correspondence of reality. If a journalistic narrative aims to be knowledge, it cannot be just any interpretation. It has to be a plausible and highly explicable interpretation. These conditions become more evident inthe analysis of true communication, bySerrano (1998). For him, communication is only true when the data is objective, significant and valid. Objective information refers to data from reality. It becomes significant when it demonstrates that the data of reference, outside of being reliable, is also explicable. And it becomes valid because, outside of being reliable and explicative, the data is sufficient to meet the praxis of communication.

Journalistic discourse however has to base itself on a demonstrative argument with a rhetorical discourse because, as Aristoteles states (1990, p.7, our translation) ${ }^{6}$, "we give credit, especially when we understand that something is demonstrated"7. It is the nature of journalism as it is with rhetoric, to lead us to believe (BERGER, 1996; SERRA, 2006b). In this way, arguing about why the facts were interpreted one way and not the other is a part of journalism (SOUSA, 2002), why this knowledge was chosen over another one ${ }^{8}$.

Seeing as how journalistic knowledge is not an exact science, the truth it aspires to is always an approximation. There is no way of avoiding interpretations, because any fact will be mediated by someone. Therefore, the problem is not with the actual interpretation but with the unjustified and unexplained interpretation."To know or say the truth is fatally connected to different levels of certainty or cognitive reliability which we are compelled to admit: certainty, probability, likelihood and conjecture [...]" (SOUSA, 2002, p.4).

Using demonstration and rational arguments requires journalistic discourse to consult a "universe of common ideas" (ARISTOTELES, 1990, p.8, our translation) ${ }^{9}$, shared by both orator and interlocutor. As Arendt said (1993, p. 40), "since each object appears in a singular perspective for each individual, the context in which it appears is the same for every part". This common world of sharing 
provides a kind of remedial subjectivity, according to Arendt: even though an object can appear different to others, it is still the same object. This common, mundane context is where journalistic discourse lies and where the foundations of its legitimacy reside. Intersubjectivity is a pre-requisite for measuring credibility. If we consider that the source and the interlocutor share a common symbolic universe, an investigation can begin on arguments or proofs that reside or in "the character of who speaks, other times in the listener or even still in the actual discourse, who demonstrates what it appears to demonstrate" (ARISTOTELES, 1990, p. 10, our translation) ${ }^{10}$.

As we have mentioned, the first condition that makes journalism a justified true belief, the truth, is supported in a relationship of correspondence with reality. It is a propositional truth that consolidates inasmuch as the reader can measure the level of trust between the journalistic report and the actual fact. For this, journalism uses discursive choices like photography, special sources, details of the facts, explanation for the type of approach and contextualization of the events. A journalistic report is always an interpretation, and as such,trusting the facts occurs on levels or degrees of certainty; the truth is always an approximation. The inevitable subjectivity of journalistic reporting is not in question here since subjectivity is necessarily dependent on the search for the truth. What is in question is not the interpretation itself, but the justification of it, its plausibility, and its explanatory power - which brings us to the second condition of journalism as a justified true belief: the pillar of justification.

\section{JUSTIFICATION IN JOURNALISM}

Knowledge produced by journalism also becomes reliable in that it creates methods and processes of calculation that maintain the truthfulness of its reports. They are thorough and have pluralism in vision, objectivity and clarity when presenting and describing facts, and impartial when selecting what should be told. Looking at it from the reliability theory of Goldman (1979), journalism becomes a true and objectively justified belief because it is produced by processes, mental faculties and reliable methods. It is a production of news aimed at truthfulness. That is because, as Graham (2010) defends, when a system functions according to the expected standard, our 
understanding of it will be based on truthfulness and reliability. In other words, when it does the work it is supposed to, journalism guarantees its credibility.

The perception of these elements by the reader provides evidence and reason for belief in witness journalism. This evidence constitutes justification, the second condition that turns true belief into knowledge. Justification ${ }^{1}$ is that which is capable of generating arguments in defense of a belief. Journalism becomes knowledge when it builds a likely testimony of reality, basing its information on methods and processes that try to reduce error and false facts. The fact that journalism is a specialized and collective work with a hierarchical structure of reporters, editors, secretaries and editor-inchiefs obligated to debate issues, check and evaluate sources and revise texts before publishing them can be verified in the context of justification, as Hardwig (1991) suggests when he discusses the role of trust in producing knowledge.

The elements in journalism for a belief such as a reliable testimony of reality are present in the contract of communication (CHARAUDEAU, 2010). An agreement of sorts between interlocutors, the contract ${ }^{12}$ has five conditions that not only assure the understanding of journalism discourse but also guide the reader's measurement of credibility for what is told: why it is told, what is told, who told it and to whom, under what conditions it was told and how it was told. Generally speaking, the end result of journalism is to produce reports on the world and humankind according to criteria of newsworthiness and importance, and use strategies to justify the truthfulness of what is told. In order to do this, journalists need to imagine a reader who is capable of recognizing the rules of discourse and consider what is told to be valid. On the other hand, the reader should also understand what is said, using their knowledge of what journalism should be and what they think a journalist's ability should be. The actual collective and discursive nature of journalismgives it an ethos which came before it, that is to say, it is not exclusively connected to the act of telling or testimony. As Maingueneau (2005) writes, the reader builds representations of the ethosfrom the teller (source) before being spoken. And the pre-discursive ethos of journalism implies a presumption of credibility(BURGE, 1993). The reader presumes the degree of credibility of journalism based on previous experience as a reader and on identifying values associated with credibility.

The conditions of reception come into play while reading. They 
involve the reader's previous experience with journalism, their beliefs, likes and preferences which all condition their interest and interpretation of journalistic reports. An individual, as a member of a community, looks at the information presented in journalism as a series of other reports or sources, presumably independent of each other, which he or she has already had contact with and learned from (ADLER, 2006).

In journalism, we maintain that justification is supported by the methods and processes used for reducing errors and the occurrence of false facts. The justifications presented by journalism towards believing in its testimony are also supported by the moral and ethical duty the professionals uphold.

In philosophy, Moran (2006) shares the idea that there is an ethical commitment within a communicative relationship that is similar to the contract of journalistic communication being the angle we use to investigate the relation between journalism and the reader. According to his Assurance View ${ }^{13}$, the subject's right to believe in someone who offers testimony resides in the teller's commitment to giving their word and clarifying their intention for the report. According to Moran, the interlocution would hold a kind of non-evidential justification for belief in the testimony ${ }^{14}$. It isn't only trusting in what is told, but also in the figure who tells and the moral commitmentaround intersubjective communication. This moral commitment is even greater in journalism as its main objective is to communicate information about the world. The journalist has special obligations to provide verified information on current events to the public, and to do so according to the criteria of importance and newsworthiness which the reader evaluates more precisely than he would a taxi driver commenting on the weather. As Moran sees it, it is as if journalism invited the reader to give a vote of confidence for its report.

Due to having special obligations, journalism provides guarantees towards belief in its reports. This is because no individual is capable of putting together the information themselves in order to verify the authenticity of a report. For this reason the guarantees that sources offer must provide some of the truthfulness the public needs, an assumption that integrates the contract of communication. The reader's justification for believing in a testimony is not based only on inferences and evidence thatthe source tells the truth when confronting the report with reality, but in inferences around the reliability of the source (WEINER, 2003), which refers to the condition of identity (ethos) in journalism. "When we believe based 
on testimonial justification, we see the teller as someone who will choose to be trustworthy. The teller's testimony is connected to the facts she reports, but only because shethe teller chooses to make that connection" (WEINER, 2003, p. 25) ${ }^{15}$.

We agree with Weiner when he said that the moral intention of the source also bases belief in the testimony. It isn't only the correspondence between the report and the events narrated that uphold the belief, but an ethical relationship established between the narrator and the reader. This condition is no different in journalism. There isn't only reliability in what is said, but also in the figure of who tells and in the moral commitment involved in communication. Credibility as a qualitative perception would form in this relationship, supported by this moral commitment which consolidates over the course of time in so far as the source of information gains the public's trust by being a recognized authority and a likely argument. The elements of the contract of journalistic communication point towards a path built on the ideas of truth and credibility. It is exactly these ideas that journalism has used to establish itself as a form of knowledgewith its own characteristics and achieves legitimacy through its public.

The procedures that ensure the effects of truth and the perception of credibility guarantee the existence of the contract noncompliance leads to tensions. A worrying feature of judging credibility is the tendency to always remember the false testimonies, the ones we pay the most attention to (ADLER, 2006). In cases where evaluation of credibility was negative, even if it were specific to just one report, the remembrance of the error will set the tone and affect the judgement of the other reports. We had difficulties talking about missteps in relative terms, especially when dealing with a source having special obligations to provide precise and verified information.

The contract of journalistic communication is presumed in the explicit principles laid out in the Code of Ethics for Brazilian Journalists (CÓDICO, 2007) regulating the practice. Some of these rules are: a) the journalist's fundamental commitment is to the truth, and his work is based on accurate accounts and proper dissemination, b)it is the journalists duty to disseminate all the facts of interest to the public, c) to fight against and report all forms of corruption, especially when the objective is to control information, d) journalists are responsible for all information they report as long as their work has not been touched by third-parties, e) journalists must not disseminate facts of personal interest or that would benefit them financially. 
From an epistemological perspective, the existence of the deontological code does not only regulate the practice of journalism, it also gives the reader another reason to believe in journalism. It is a guarantee that is maintained and consolidated so that the practice approaches its deontology. An individual who reads a newspaper knows in advance that it is non-fiction, and being non-fiction, it must be as close to the facts as can be; established and written objectively and according to criteria of public importance and interest.Even if the subject is not naive to economic and political interests of a particular media company, and is aware of errors and previous imprecisions from said company, the expectation is that the material is true since it must have gone through the professional verification and editing processes behind journalism. This is what we call presumption of credibility.

This presumption brings journalism to be recognized as an expert knowledge (MICUEL, 1999), a term coined by Giddens (1991) ${ }^{16}$ which refers to systems of technical excellence or professional ability that organize huge areas of material and social environments. In contemporary societies, the expert systems or knowledge would have the role of organizing and supplying human necessities in a world marked by the distancing of time and space in social relations. A system like this requires the public to trust in its specialized ability.

Miguel (1999) uses the example of a doctor. As a general rule, when someone goes to the doctor, they are not capable of evaluating if the treatment they receive is correct or incorrect. But they trust in the specialized knowledge of the doctor. Even though the reader is not aware of the criteria behind releasing news, they apparently trust in the veracity of what is being told and the importance the press gives to it. The reader assigns journalism with the task of producing up-to-date news on topics that are important to life that they would otherwise have difficulty in obtaining for themselves. Trust in journalism, which presupposes an evaluation of credibility, bases itself on the underlying rationale of the practice; in its end product and specialized ability.

There is a tension in the field of journalism being the nature of its discourse. The authority of journalism is derived from the ability within the field to reconstruct the discourse of news events based on journalist testimony orfrom third-parties who have specific knowledge of the issue under discussion. This is why a journalistic text is "a clipping, a 'collage' or 'combination' of observation, description and interpretation for journalist, production team and information 
sources" (FRANCISCATO, 2005, p. 168). The credibility of journalism is established on the authority of the sources used and a proper authority based on specialized competence and trustworthy methods of building a balanced, polyphonic report. There is a transfer of mutual credibility which helps build up the reputation of the journalistic institution.

The conditions under news production and dissemination also have an important impact on credibility in journalism. Goldman (1999) states thattechnology and economy, while very prominent elements of journalism, could be barriers to the truth ${ }^{17}$. The fact that journalistic companies are companies like any other has important repercussions on producing true knowledge. For Goldman, this is a fundamental point in the study of journalistic credibility, it is directly associated to its level of independence from advertisers and other social actors.

A study conducted by Fogg et al (2002a) shows that individuals look less favorably on sites that use banners and advertising. Ostertag $(2010)^{18}$ came to a similar result. In a qualitative analysis based on understanding why and how individuals use the media to inform themselves about the world, Ostertag discovered that PBS (the Public Broadcasting Service) in the United States is regarded as a "safe network" because of its non-commercial profile. Those interviewed said they trusted PBS more because it appears to be more "legitimate", less "biased" and "more balanced" than commercial networks of information (OSTERTAG, 2010, p. 601-602).

Something else to consider is market conditions. The lack of competition between journalistic organizations is a problem when building knowledge, says Goldman (1999). When a story is told untruthfully in environments where no competition exists, the public cannot even consult other sources of information ${ }^{19}$.

\section{FINAL CONSIDERATIONS}

How journalism produces knowledge is one of the epistemic questions that is crucial towards understanding its nature. In this article, we used contributions from philosophy and proposed to think of journalistic knowledge from the point of view of Epistemology which understands knowledge as a justified true belief. We defend that for journalism, just as for philosophy, the conditions of truth and justification are the pillars that hold up the belief in its discourse. Journalism becomes trustworthy as it can prove its 
own testimony. Its social justification is based on proof such as photographs, the details of facts, quoting specialized sources that guarantee its reports are accurate that demonstrate or appear to demonstrate, as Aristoteles (1990)holds. It is under these conditions that journalism establishes itself as expert knowledge, by telling about the world and the acts of humanity.

Contemporary network journalism (HEINRICH, 2011) poses many questions that expand on the issue of credibility and trust between subjects. Despite an increasingly more plural scene, or maybe exactly because of it, journalism continues to be a procedural phenomenon involving subjects with diverse interests and developing a relationship whose paths are truth and justification.

As a form of knowledge, journalism is a justified true belief. This means it becomes knowledge when the subject qualifies what before was just a mere belief, taking on a more trustworthy journalistic discourse since it demonstrates justifiably that it tells the truth or that it searched for the truth by means of technical and professional procedures. Simple beliefs become true and justified, in other words, knowledge. On the operating path of this process of transformation is the concept of credibility.

*This paper was translated by Lee Sharp.

\section{BIBLIOGRAPHY}

ABBAGNANO, Nicola. Dicionário de Filosofia. São Paulo: Martins Fontes, 2007. $1.210 \mathrm{p}$.

ADLER, Jonathan. Epistemological problems of testimony. In: ZALTA, Edward (org.). Stanford encyclopedia of philosophy.Stanford: Stanford University, 2006. Available at: <http://plato.stanford.edu/ entries/testimony-episprob/>. Accessed on: Jan.11, 2015.

ARENDT, Hannah. A vida do espírito. $4^{\mathrm{a}}$ ed. Rio de Janeiro: Relume Dumará, 2000. 392 p.

ARISTÓTELES. Retórica. Madrid: Centro de Estudios Constitucionales, 1990. $216 \mathrm{p}$.

AUSTIN, John. Philosophical papers. Oxford: University Press, 1961. 
Available at: <https://archive.org/details/philosophicalpap013680mbp $>$. Accessed on: Jan.10, 2015.248 p.

BENETTI, Marcia. O jornalismo como gênero discursivo.Galáxia, São Paulo, n. 15, p.13-28, 2008.

BERGER, Christa. Em torno do discurso jornalístico. In: FAUSTO NETO, Antonio; PINTO, Milton José (org.). O indivíduo e as mídias. Rio de Janeiro: Diadorim, 1996, p. 188-193.

BURGE, Tyler. Content preservation.The philosophical review, Durham, Duke University, v. 102, n. 4, p.457-488, 1993.

CHARAUDEAU, Patrick.Discurso das mídias. São Paulo: Contexto, 2010. 285 p.

CHAUI, Marilena. Convite à filosofia. São Paulo: Ática, 2001. 440 p.

CÓDICO de Ética dos Jornalistas Brasileiros. Brasília: Fenaj, 2007. Available at: <www.fenaj.org.br>. Accessed on: June.16, 2011.

COX, James; GOLDMAN, Alvin. Accuracy in journalism: an economy approach. In: SCHMITT, Frederick (org.). Socializing epistemology: the social dimensions of knowledge. Boston: Rowman\& Littlefield Publishers, 1994. p. 189-215

FOGG, B. J. et al. Stanford-Makovsky web credibility study 2002:investigating what makes a web site credible today. 2002. Available at: < http://captology.stanford.edu/>. Accessed on: Feb.12, 2015.

FOLEY, Richard. Intellectual trust in oneself and others. Cambridge: Cambridge University Press, 2000. 196 p.

FOUCAULT, Michel. A ordem do discurso. $5^{a}$ ed. São Paulo: Loyola, 1999. 79 p.

FOUCAULT, Michel. Microfísica do poder. São Paulo: Graal, 1979. 295 p.

FRANZONI, Sabrina; RIBEIRO, Daiane Bertasso; LISBOA, Sílvia. A verdade no jornalismo: relações entre discurso e prática. Verso e Reverso, XXV (58), p. 45-52, January-April 2011.

GENRO FILHO, Adelmo. O segredo da pirâmide:para uma teoria marxista do jornalismo. Porto Alegre: Tchê, 1987. 230 p.

GETTIER, Edmund. Is a justified true belief knowledge? Analysis, Oxford, V. 23, n. 6, p. 121-123, 1963.Available at: <http://philosophyfaculty. ucsd.edu/faculty/rarneson/Courses/gettierphilreading.pdf $>$. Accessed on: Feb.12, 2015.

GIDDENS, Anthony. As consequências da modernidade. $5^{a}$ ed. São Paulo: Editora da Unesp, 1991. 156 p. 
GOLDMAN, Alvin. A causal theory of knowing.The journal of philosophy, Nova York, v. 64, n.12, p. 357-372,1967.

GOLDMAN, Alvin. What is justified belief? In: PAPPAS, G. S. Justification and Knowledge. Dordebrecht: Reidel Publishing Company, 1979. Available at: <http://www.andrew.cmu.edu/user/kk3n/epistclass/ goldmanjust.pdf>. Accessed on: Feb.12, 2015. p. 89-104.

GOLDMAN, Alvin. Knowledge in a social world. Oxford: OxfordUniversity Press, 1999. 424 p.

GOLDMAN, Alvin. Pathways to knowledge. Oxford: Oxford University Press, 2002. p. 224.

GOLDMAN, Alvin. Social epistemology. In: ZALTA, Edward (org.). Stanford encyclopedia of philosophy.Stanford, 2010.Available at: <http:// plato.stanford.edu/archives/sum2010/entries/epistemology-social>. Accessed on:Feb.12, 2015.

GRAHAM, Peter. Testimonial entitlement and the function of comprehension. In: HADDOCK, Adrian; MILLAR, Alan; PRITCHARD, Duncan (org.). Social epistemology. Nova York: Oxford University Press, 2010. p. 148-174.

HARDWIG, John. The role of trust in knowledge.The journal of philosophy, Nova York, v. 88, n. 12, p. 693-708, 1991.

HEINRICH, Ansgard. Network journalism: journalistic practice and interactive spheres. New York: Routledge, 2011.272 p.

JOYCE, James. Bayes' theorem. In: ZALTA, Edward (org.). Stanford Encyclopedia of Philosophy. Stanford: Stanford University, 2008. Available at: <http://plato.stanford.edu/entries/bayes-theorem/>. Accessed on: Feb.12, 2015.

KANT, Immanuel. Crítica da razão pura. Rio de Janeiro: Edições de Ouro, 1970. 255 p.

KIRKHAM, Richard L.. Teorias da verdade. São Leopoldo: Editora Unisinos, 2006. 500 p.

LISBOA, Sílvia. Jornalismo e a credibilidade percebida pelo leitor: independência, imparcialidade, objetividade, honestidade e coerência. Dissertação (Mestrado em Comunicação). Universidade Federal do Rio Grande do Sul. Porto Alegre, 2012. Available at: <http://www.lume.ufrgs. br/handle/10183/54507>.

MAINGUENEAU, Dominique. Ethos, cenografia e incorporação. In: AMOSSY, Ruth (org.). Imagens de si no discurso: a construção do ethos. São Paulo: Contexto, 2005. p. 69-92.

MEDITSCH, Eduardo. O conhecimento do jornalismo. Florianópolis: 
Editora da UFSC, 1992. 100 p.

MEDITSCH, Eduardo.O jornalismo é uma forma de conhecimento? Biblioteca On-line de Ciências da Comunicação. Covilhã: Universidade da Beira Interior, 1997. Available at: <http://www.revistas.univerciencia. org/index.php/mediajornalismo/article/viewFile/1084/5273>. Accessed on: Feb. 12, 2015.

MIGUEL, Luis Felipe. Jornalismo como sistema perito. Tempo social, São Paulo,v. 11, n. 1, p. 197-208, 1999.

MORAN, Richard. Getting told and being believed. In: LACKEY, J.; SOSA, E. (org.). Epistemology of testimony. New York: Oxford, 2006. p. 272-306.

OSTERTAG, Stephen. Establishing news confidence: a qualitative study of how people use the news media to know the news-world.Media, culture and society, Londres, v. 32, n. 4, pg. 597-614, 2010.

PARK, Robert. A notícia como forma de conhecimento: um capítulo dentro da sociologia do conhecimento. In: BERGER, Christa; MAROCCO, Beatriz (org.). A era glacial do jornalismo: teorias sociais da imprensa. V. 2. Porto Alegre: Sulina, 2008. p. 51-70.

PEUCER, Tobias. Os relatos jornalísticos. Estudos em Jornalismo e Mídia. V. 1, n. 2, Florianópolis: UFSC, 2004. p. 13-29.

SERRA, Paulo. O princípio da credibilidade na selecção da informação mediática. Biblioteca On-line de Ciências da Comunicação,Covilhã, 2006. Available at: <http://www.bocc.ubi.pt/pag/serra-paulo-credibilidadeseleccao-informacao.pdf>. Accessed on: Feb. 12, 2015. 12 p.

SERRANO, Manuel Martin. Análisis metódico de la verdad en la comunicación. Diálogos, Santiago de Cali, 1998. Available at: < http:// www.dialogosfelafacs.net/wp-content/uploads/2012/01/20-revistadialogos-analisis-metodico-de-la-verdad-en-la-comunicacion.pdf $>$. Accessed on: Feb.12, 2015. 9 p.

SOUSA, Américo de. A retórica da verdade jornalística. Biblioteca Online de Ciências da Comunicação.Covilhã, 2002.Available at: <http://bocc. ubi.pt/pag/sousa-americo-retorica-verdade-jornalistica.html>. Accessed on: Feb.12, 2015.

WEINER, Matthew. The assurance view of testimony. Papers by Matthew Weiner (site pessoal). 2003. Available at: <http:// mattweiner.net/papers/weiner_assurance_view.pdf $>$. Accessed on: Feb.12, 2015 


\section{NOTES}

1 This is the most accepted concept of knowledge in Epistemology, although not the only one. This has been disputed by Gettier (1963) in a three-page article. He puts forth the counter example that an individual could be justified in believing a falsity if he believes it to be true. Gettier goes on to suggest that a fourth condition should be added to the others when transforming a justified true belief into knowledge. He does not propose a solution to the problem, yet many philosophers have tried to provide an answer to this issue.In defense of the three conditions (truth, belief and justification) epistemologists have formulated theories of justification that would avoid a justified belief in a falsity. Goldman (1967) responds to Gettier by saying that knowledge requires a causal relationship between fact and belief. The problem is that, in some cases like knowledge of mathematics, there are no facts to associate to the belief as they are abstractions (FOLEY, 2004) - a problem that Goldman later resolves using a more open idea of facts. The discussion is far from reaching a conclusion, but knowledge as a justified true belief continues to be the most supported concept in Epistemology.

2 For more on truth in philosophy, see Abbagnano (2007), Chaui (2001), Goldman (1999) and Kirkham (2003).

3 Goldman (1999) questions the widespread idea that the correspondence theory needs a single category for truth bearers (like the facts) for its application. Some propositions are true because they are based on concrete events and others are true because of their relationships to abstract entities. Goldman believes the truth to be a post-semantic concept: it is only after a proposition or any other thing bearing the truth that the question of truth can be raised. This opens up the possibility of applying this concept of truth to journalism.

4 It is a simple mathematical equation of calculating conditional probabilities. It is widely used in Epistemology, for statistics and deductive logic (JOYCE, 2008).

5 We can also put truth in doubt as a status and a qualification of importance, as Foucault (1979) states. This is a particularly rich idea to put towards thinking about meanings produced by journalistic discourse (FRANZONI, RIBEIRO, LISBOA, 2011).

6 "[...] pues prestamos crédito sobre todo cuando entendemos que algo está demostrado."

7 In the demonstration, Aristoteles coined the expression enthymeme which is the principle instrument of persuasion in Aristotelian terminology (SOUSA, 2000). Enthymeme is an inference or deduction, 
a kind of logic syllogism but without the same rigidity.Like journalistic discourse, rhetoric is not a scientific discourse, and gives way to enthymemes, in other words, it presents truthful premises that are either explicit or implied.

8 As Sousa (2002, p.4) suggests, the meaning of journalistic objectivity can also be thought of as: "An affirmation will be more objective the more justified it is".

9 "[...] sino que es preciso que los argumentos y los razonamientos se hagan mediante nociones comunes [...]."

10 "[...] pues unos residen en el carácter del que habla, otros en poner en cierta disposición al oyente, otros en el mismo discurso, por lo que demuestra o parece demostrar."

11 The central issue of debates on justification is that, in many instances of knowledge, not one argument appears to be involved which favors belief. In other situations, it is not certain how to define a sufficient justification to prove that a true belief is knowledge.

12 In another text (BENETTI, 2008), we adapt the contract of communication to certain aspects of the field of journalism to maintain why and how journalism establishes itself as a form of specific discourse.

13 The concept is called Assurance view in English. A free translation of this might be "thesis of guarantee".

14 Some authors, such as Weiner (2009), argue if justification based on the belief of what the other tells is true would not be evidence. Weiner states that guarantees are a kind of evidence for justification.

15 "When we believe based on testimonial justification, we see the teller as someone who will choose to be trustworthy. The teller's testimony is connected to the facts she reports, but only because the teller chooses to make that connection."

16 Brazilian translations and Miguel (1999) use the term "expert systems", but in English the term is known as expert knowledge".

17 Goldman (2002) holds that economic and technological issues condition the reports, thereby losing honesty and accuracy. He gives an example of a study done by the Journal of the American Medical Associationon how medical research results can be influenced by their funders.According to the study, research funded by laboratories tends to favor the medicine being tested when compared to other studies on medicines funded by non-profit organizations. Unfavorable findings on the drugs were found in $38 \%$ of studies paid by non-profit organizations while this number was only $5 \%$ for the studies paid by large laboratories. 
18 Ostertag (2010) held in-depth interviews with 47 people who responded spontaneously.

19 For Goldman (1999), there is still no consensus that freedom generates the most beneficial environment for producing and social dissemination of knowledge. But a strong trend, called FreeSpeach Theory, says that the truth always prevails in these cases.There is more chance for the truth to appear when the ideas and reports circulate freely.When there is competition and more knowledge, the companies feel compelled to reveal the truth about their products.

Sílvia Lisboa is Master's Degree in Communication and Information from the Post-Graduate Program in Communication and Information (PPGCOM) at the Federal University of Rio Grande do Sul (UFRGS). lisboasilvia@gmail.com

Marcia Benetti is PhD in Communication at the Pontifícia Catholic University of São Paulo (PUCSP).Professor at PPGCOM/UFRGS. Researcher for CNPq. marcia.benetti@gmail.com 